UDC 621.791.052

\title{
MODELING OF CRACK OPENING MODE SIF FOR A CRACK IN A THIN-WALLED STRUCTURAL CHANNEL BEAM
}

\author{
Mykola Pidgurskyi; Mykola Stashkiv; Ivan Pidgurskyi
}

\author{
Ternopil Ivan Puluj National Technical University, Ternopil, Ukraine
}

\begin{abstract}
Summary. The analysis of engineering methods for determining stress intensity factors (SIF) for defective elements of open profile (channels) under bending is carried out. Mathematical models are created and dependences for calculation of SIF are deduced using two methods: using nominal stresses in net-section and using change of the inertia-moment of the profile cross-section. The obtained results are compared with the data of SIF for the crack in the channel obtained during simulation modeling using finite element method.
\end{abstract}

Key words: stress intensity factor, edge crack, structural channel, finite element method.

Formulation of the problem. An important area of strength calculations from the standpoint of fracture mechanics is the prediction of the durability of elements of machines and structures with fatigue cracks, which develop under the action of operational load. These methods find practical application in mechanical engineering and construction in relation to thin-walled rod elements of structures that perceive variable in time loadings and the stage of operation of which after the formation of a crack is essential to determine the lifetime of the structural elements.

The experience of operation of welded load-bearing structures of mobile machines and building structures shows that welding defects are centers of initiation of fatigue cracks [1, 2], and the process of their development takes a significant share (from 50 to $90 \%$ ) of the structure lifetime from the beginning of operation to the limit state.

Thus, the objects of calculation are thin-walled rod elements of load-bearing structures (machine frames, bridge beams, frames of industrial buildings), where the edge and surface fatigue cracks are develop, which are later transformed into through-thickness ones. The calculation model should take into account on the one hand the main features of the real object and the factors influencing the results of the calculation, and on the other hand should allow the calculation to be performed by existing methods and tools. The main factors influencing the durability are the geometry of the structural element and the load-bearing structure in general, the type and properties of the loading process that determine strain-stress state (SSS), mechanical properties (crack resistance characteristics) of the material in the area of growth of fatigue cracks.

Analysis of the available research. In load-bearing structures, thin-walled rod elements with channel-type cross-sections, I-beams, T-beams, angles, closed type profiles, etc. are used. Within the linear fracture mechanics of materials, the study of SSS of frame structures, in the presence of cracked defects, is reduced to determining the stress intensity factor (SIF). Similar problems are quite complex for mathematical consideration taking into 
account the real load and geometry of structures, so the direct application of analytical methods in engineering problems is quite limited [3-5].

In this regard numerical methods are promising [6-8]. The most effective among them is the finite element method (FEM), which due to its versatility, fairly simple interpretation and well-developed mathematical software allows avoiding the difficulties that arise when using analytical methods [4]. At the same time, numerical methods are quite inefficient, time-consuming and have a high computational cost and require powerful computer equipment.

A number of researchers [9] determine the SIF for cracks that develop in complex structural elements experimentally using tensometry methods, and others. This method deserves attention, especially for important structures, but it is difficult to interpret for problems, for example with a different configuration of the element.

Analysis of the operation of frame structures of mobile machines shows that one of the main types of load are bending moments. In [3], the SIF are estimated for the edge crack in the channel flange for the case of pure bending was performed by the boundary interpolation method. This problem is asymmetric. Herewith, two boundary cases are considered: a crack of small size, which develops in the flange of the channel and a crack of great length, which spreads in the wall of the channel. For each of these cases, the correction function is interpolated to determine the SIF for the crack that develops in the channel during pure bending.

In [3] the development of a crack in a closed element of mobile crane frame is considered. The crack is symmetrical and propagates in the lower wall of the profile first as a surface crack (first stage), and then is transformed into through-thickness crack and develops along the lower wall (second stage). Then the crack passes to the vertical walls of the element and propagates along them (third stage). Thus, the crack has a broken contour. The SIF definition problem is considered for each stage separately, and the transition from one stage to another is not interconnected. Despite the relative simplicity of the method, the solution of the problem significantly depends on the choice of the relative crack length, which is included in the polynomial of the correction function for SIF when considering the individual stages of crack propagation.

Objectives of the research. Directly for the engineering problems mentioned above, it is appropriate to construct relatively simple, albeit less accurate, dependences for determining SIF for cracks in elements with complex cross-section, in which lower accuracy of calculation is compensated by lower calculation cost (limit interpolation method [10], cross section method) [11]).

To solve such problems, the authors proposed quite simple and clear engineering methods for determining SIF for open cross-section profiles [13]:

a) using nominal stresses;

b) using the change of the inertia moment of the profile cross-section,

theoretical foundations of which are laid in $[3,12]$, with subsequent assessment of the accuracy of these methods by comparison with the modeling results.

Statement of the problem. Analysis of the operation of frame structures shows [3] that the main type of their load is bending loads. In this regard, we consider the main provisions of the SIF calculation for cracks that develop in the real profile elements of frame structures, in particular, in the channel, under the action of only the bending moment $M$.

We distinguish two characteristic stages of crack development in the channel profile: the through-thickness crack arises at the edge of the horizontal flange and develops along it (Fig. 1, a); the crack develops in the web of the channel (Fig. 1, b). 


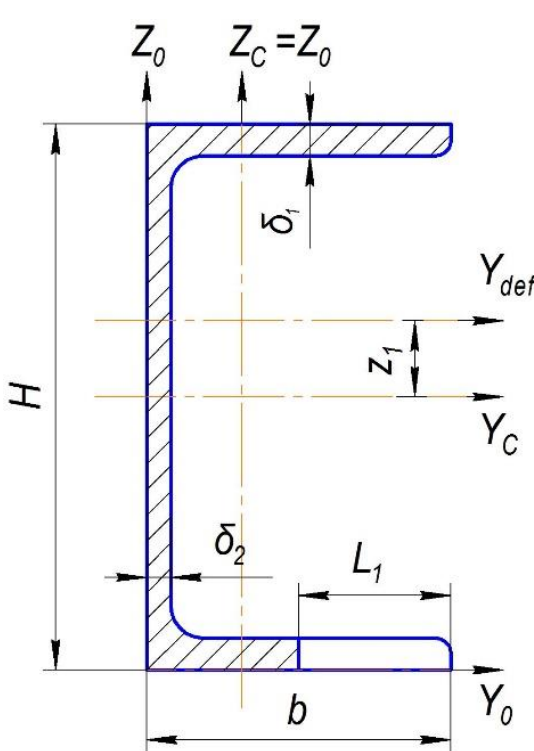

a)

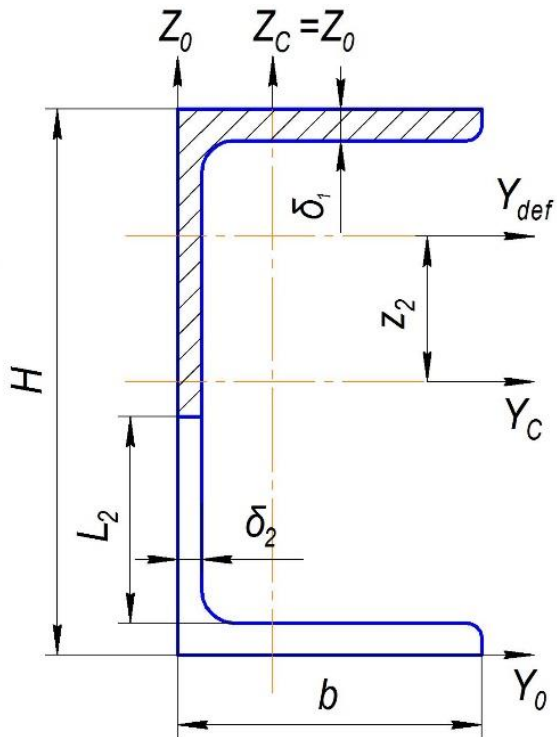

b)

Figure 1. Characteristic stages of the edge crack growth in the channel

To estimate the SIF for the cases under consideration, two methods are applied: usnig the nominal stresses and using the change in the inertia moment of the profile cross-section, which are proposed in [13]. method:

The following dependences of SIF calculation are obtained using nominal stresses - for the first stage of crack development:

$$
K_{I}^{(1)}=M \frac{H}{2} \frac{1}{I_{Y}} \sqrt{\pi L_{1}} F_{1}\left(\varepsilon_{1}\right)
$$

where $L_{l}$ is the crack length which is determined from the dependence $\varepsilon_{1}=\frac{L_{1} \delta_{1}}{\left(H-2 \delta_{1}\right) \delta_{2}+2 b \delta_{1}}$; $M \frac{H}{2} \frac{1}{I_{Y}}=\sigma$ are normal stresses in the nondefect channel cross-section, $\mathrm{MPa}$; $I_{Y}$ is the inertia moment of the nondefect channel cross-section, $\mathrm{m}^{4}$ :

$$
I_{Y}=\frac{\delta_{2}\left(H-2 \delta_{1}\right)^{3}}{12}+2\left(\frac{b \delta_{1}^{3}}{12}+b \delta_{1}\left(\frac{H-\delta_{1}}{2}\right)^{2}\right)
$$

- for the second stage of crack development:

$$
K_{I}^{(2)}=M \frac{H}{2} \frac{1}{I_{Y}} \sqrt{\pi\left(L_{2}+b\right)} F_{2}\left(\varepsilon_{2}\right)
$$

where the crack length $L_{2}$ is determined from the dependence $\varepsilon_{2}=\frac{L_{2} \delta_{2}+b \delta_{1}}{\left(H-2 \delta_{1}\right) \delta_{2}+2 b \delta_{1}}$. 
The expressions of the functions $F_{1}\left(\varepsilon_{1}\right)$ and $F_{2}\left(\varepsilon_{2}\right)$ are not given due to their bulkiness. Graphically, these functions for the channel № 10 are presented in Fig. 2.

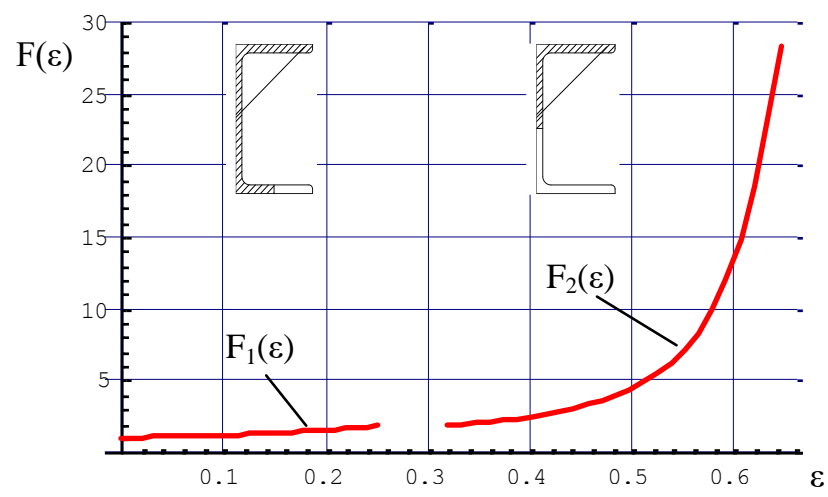

Figure 2. Graphic representation of correction functions for determination of SIF for different stages of crack growth development in channel № 10 (nominal stress method)

As calculations have shown, for a number of standard structural steel section such as channels profile from № 10 to No 24 the array of values of correction functions (for $0<\varepsilon<0,8$ ) can be approximated by the generalized curve (the first and second stage):

$$
\begin{aligned}
F_{1,2}^{(\sigma)} & =1.036+3.189 \varepsilon+4.481 \varepsilon^{2}-173.864 \varepsilon^{3}+309.338 \varepsilon^{4}+10999.103 \varepsilon^{5}- \\
& -80602.932 \varepsilon^{6}+232137.410 \varepsilon^{7}-306266.279 \varepsilon^{8}+154375.438 \varepsilon^{9}
\end{aligned}
$$

Graphically, the arrays of points for a number of channels from №10 to № 24 and the generalizing function $F_{1,2}^{(\sigma)}$ are presented in Fig. 3.

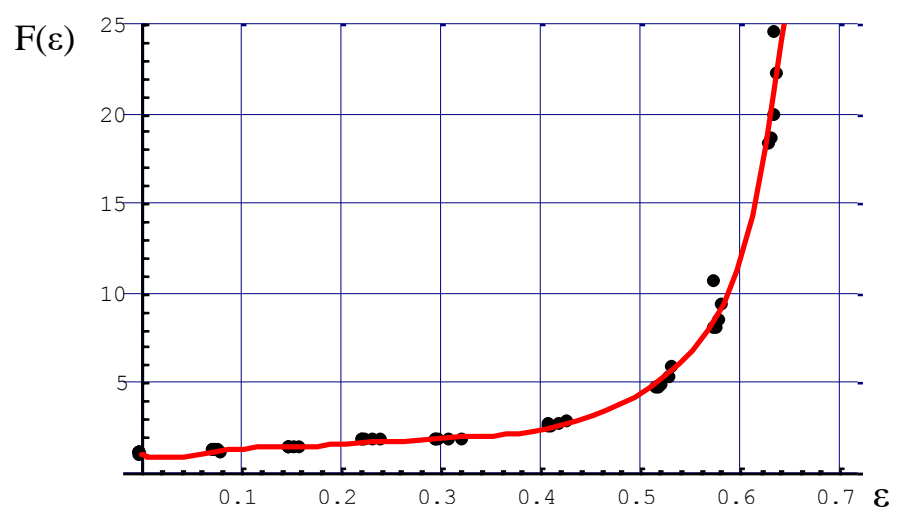

Figure 3. Generalized correction function $\mathrm{F}_{1,2}$ for a number of channels from № 10 to № 24 (nominal stress method)

The following dependences of SIF calculation are obtained using the method of the inertia moment changing of the cross-section:

- for the first stage of crack development:

$$
K_{I}^{(1 M)}=M \frac{H}{2} \frac{1}{I_{Y}} \sqrt{\pi L_{1}} F_{1 M} .
$$


- for the second stage of crack development:

$$
K_{I}^{(2 M)}=M \frac{H}{2} \frac{1}{I_{Y}} \sqrt{\pi\left(L_{2}+b\right)} F_{2 M} .
$$

The expressions of the functions $F_{1 M}$ and $F_{2 M}$ are not given due to their bulkiness. Graphically, these functions for the channel No 10 are presented in Fig. 4.

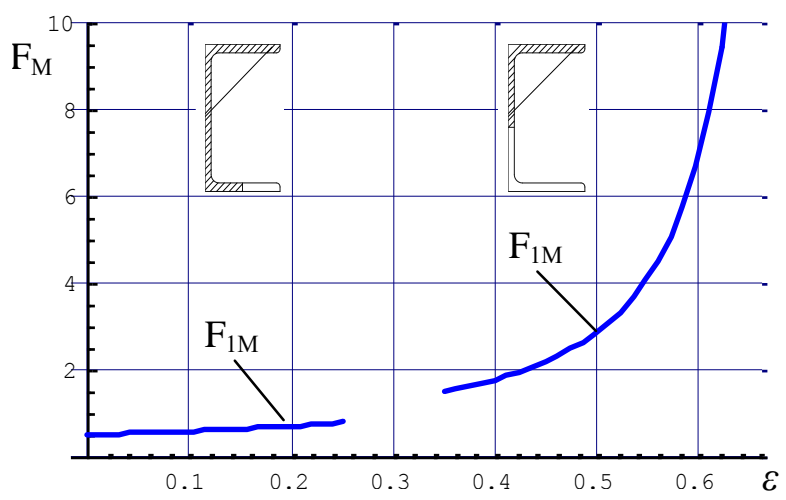

Figure 4. Graphic representation of correction functions for determination of SIF for different stages of crack growth development in channel № 10 (method of the inertia moment changing)

As calculations have shown, for a number of standard structural steel section such as channels profile from № 10 to № 24 the array of values of correction functions can be approximated by the generalized function for the total crack (first and second stage):

$$
\begin{gathered}
F_{1,2}^{(M)}=0.535+2.559 \varepsilon-65.419 \varepsilon^{2}+783.346 \varepsilon^{3}-4384.664 \varepsilon^{4}+ \\
+13139.579 \varepsilon^{5}-19656.429 \varepsilon^{6}+11509.650 \varepsilon^{7}
\end{gathered}
$$

Graphically, the arrays of points for a number of channels from № 10 to № 24 and the generalized function $F_{1,2}^{(M)}$ are presented in Fig. 5.

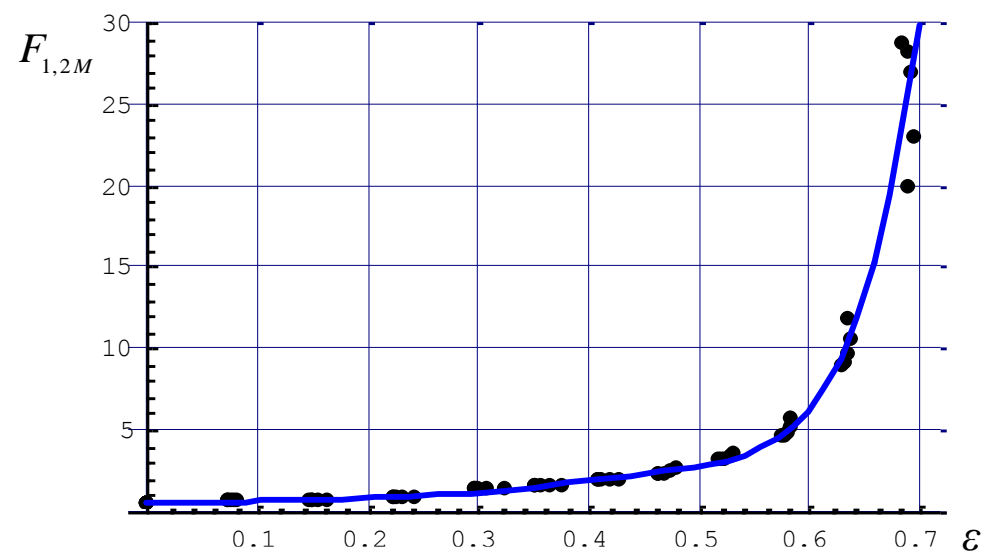

Figure 5. Generalized correction function $F_{1,2}$ for a number of channels from № 10 to № 24 (method of the inertia moment changing) 
Analysis of numerical results. In order to verify the results obtained on the basis of the proposed engineering methods for determining SIF, we will compare them with the results of simulation modeling for SIF estimation for the edge crack in the thin-walled cross-section of the channel, obtained by finite element method (FEM).

To obtain reliable results in the simulation modeling of the stress-strain state of a thinwalled element with a crack by FEM, it is necessary to ensure the construction of an adequate model of the edge crack with a correct mesh of finite elements. This task can be implemented by a number of specialized computer software, the most powerful of which is the software package ANSYS Workbench [14, 15].

For simulation of edge crack development in a thin-walled channel-type element, in order to study the stress intensity factor (SIF) at the tip of the edge trans verse crack propagating in the channel under pure bending, the tools of Fracture option of Mechanical software package in ANSYS Workbench Academic were used.

A thin-walled element with a length of $500 \mathrm{~mm}$ with cross-sectional dimensions of $100 \times 50 \times 5 \mathrm{~mm}$ under the action of bending moment $M=1000 \mathrm{~N} \cdot \mathrm{m}$ (Fig. 6, a), which creates normal stresses $\sigma \approx 35 \mathrm{MPa}$ in the defect-free channel profile (Fig. 6, b) was simulated.

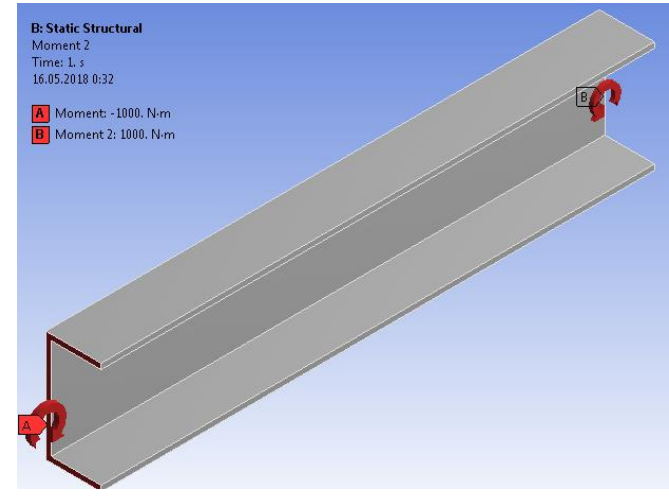

a)

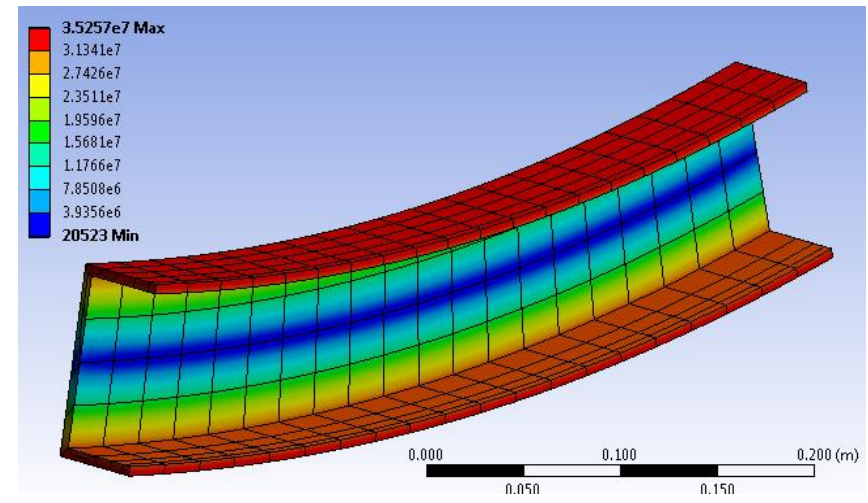

b)

Figure 6. Scheme of loading and deformation of simulated specimen

The crack length $L$ was set with a step of $5 \mathrm{~mm}$ during its propagation in the channel flange (from 5 to $45 \mathrm{~mm}$ ) and with a step of $10 \mathrm{~mm}$ during its propagation in the channel web (from 60 to $110 \mathrm{~mm}$ ).

The following restrictions are considered during simulation:

- the crack propagates strictly orthogonally to the axis of the element and the stress state at its tip is determined only by the crack opening mode SIF $K_{I}$;

- the influence of the crack on the nature of channel deformation is neglected (we consider that the thin-walled element is constantly under the action of pure bending).

The Pre-Meshed Crack tool of the Fracture option is used to model the edge crack| with ANSYS Workbench Academic software. The MultiZone method is used to create a finite element mesh. The size of the hexagonal elements of the global mesh is $25 \mathrm{~mm}$ (Fig. 7, a). To construct a local mesh at the tip of the crack, the Virtual Topology tool was used (Fig. 7, b), the crack front was divided into 15 sections with the dimensions of the local mesh elements $0.5 \ldots 2.5 \mathrm{~mm}$. 


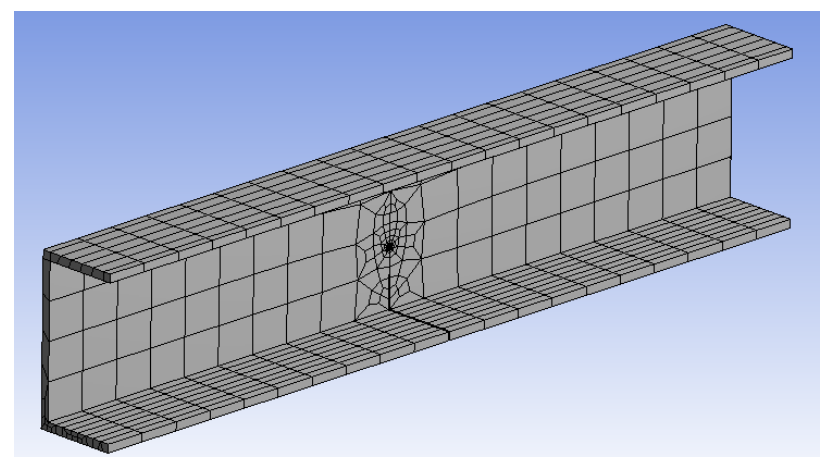

a)

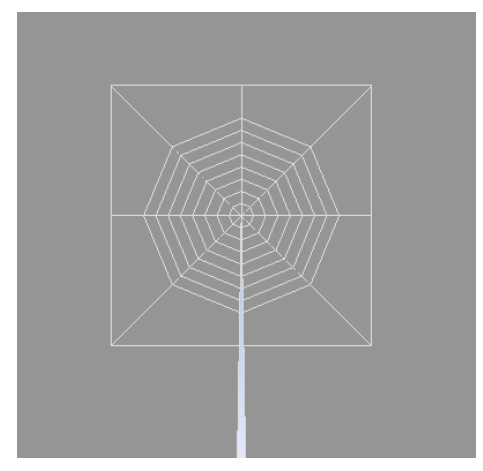

b)

Figure 7. Modeling of edge transverse crack in the channel

The results of the crack opening mode SIF $K_{I}$ calculation are presented in table 1 depending on the crack length $L$ during it propagation in the channel profile beam.

Table 1

The results of crack development simulation in the channel

\begin{tabular}{|c|c|c|c|c|c|c|c|c|c|c|c|c|c|c|c|}
\hline $\begin{array}{c}\mathrm{L}, \\
\mathrm{mm}\end{array}$ & 5 & 10 & 15 & 20 & 25 & 30 & 35 & 40 & 45 & 60 & 70 & 80 & 90 & 100 & 110 \\
\hline $\begin{array}{c}K_{I}, \\
M P a \cdot \sqrt{m}\end{array}$ & 4.5 & 6.4 & 8.1 & 9.4 & 10.9 & 12.4 & 13.7 & 15.2 & 16.7 & 22.3 & 27.4 & 33.7 & 42.5 & 55.8 & 77.9 \\
\hline
\end{tabular}

Comparison of simulation data of the SIF determination in the crack during its propagation in a thin-walled channel profile beam with the results of analytical modeling by the proposed engineering methods is given in Fig. 8. It should be noted that the method of determining SIF using nominal stresses in the net section is better consistent with the SIF results obtained in the simulation of FEM than the method of inertia moments changing (Fig. 8).

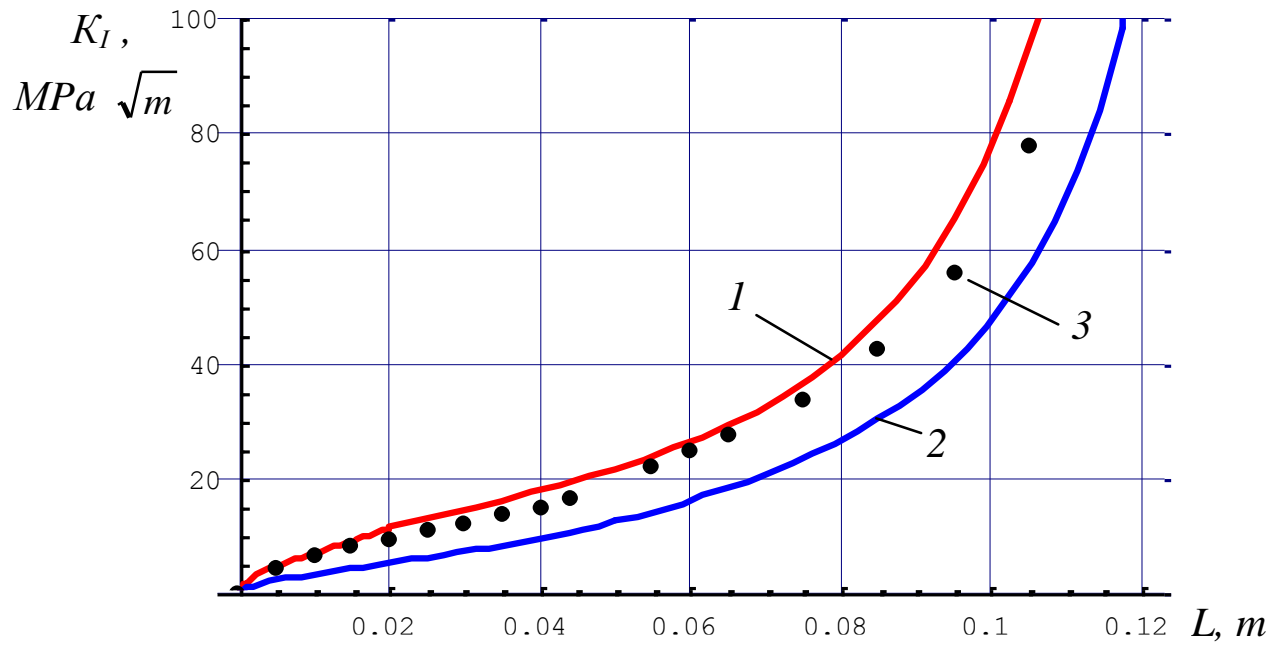

Figure 8. Comparison of the results of analytical and simulation modeling of SIF $K_{I}$ for the edge transverse crack in the channel, obtained by: 1 - nominal stress method; 2 - method of the inertia moment changing;

3 - finite element metho 
Conclusions. The results of the SIF determination for cracks developing in sections with complex configuration obtained in this article, allow a more reasonable approach of determining the lifetime and reliability increase of structures made of thin-walled open profile elements.

Further, it is advisable to consider the behavior of defective open and closed profiles under the action of other force factors, such as torques, bimoment.

\section{References}

1. Hobbacher A. F. Recommendations for Fatigue Design of Welded Joints and Components Springer 2nd ed. 2016. XVI. 143 p. DOI: https://doi.org/10.1007/978-3-319-23757-2

2. Vinokurov V. A., Kurkin S. A., Nikolaev G. A. Welded structures. Fracture mechanics and performance criteria. M.: Mechanical Engineering, 1996. 576 p. [In Russian].

3. Andrejkiv A. E., Darchuk A. I. Ustalostnoe razrushenie i dolgovechnost konstrukcij. K.: Nauk. dumka, 1992. 184 p. [In Russian].

4. Bertolini P., Eder M. A., Taglialegne L., Valvo P. S., Stresses in constant tapered beams with thin-walled rectangular and circular cross sections. Thin-Walled Structures. Vol. 137. 2019. P. 527-540, ISSN 02638231. DOI: https://doi.org/10.1016/j.tws.2019.01.008

5. Franco E. Dotti, Víctor H. Cortínez, Florencia Reguera, Mode I stress intensity factor for cracked thinwalled composite beams. Theoretical and Applied Fracture Mechanics. Vol. 67-68. 2013. P. 38-45. ISSN 0167-8442. DOI: https://doi.org/10.1016/j.tafmec.2013.10.002

6. Longgang Tian, Leiting Dong, Sharada Bhavanam, Nam Phan, Satya N. Atluri, Mixed-mode fracture \& non-planar fatigue analyses of cracked I-beams, using a 3D SGBEM-FEM Alternating Method. Theoretical and Applied Fracture Mechanics. Vol. 74. 2014. P. 188-199, ISSN 0167-8442. DOI: https://doi.org/10.1016/j.tafmec.2014.10.002

7. Pawar, Pravin \& Ballav, Raj \& Kumar, Amaresh. (2016). Finite element method analysis of stress intensity factor in i channel section. Journal of Production Engineering. 19. P. 103-107.

8. Álvarez, Morán \& Seitl, Stanislav \& Miarka, Petr. (2020). Numerical study of universal beam (i section) under bending load with crack. 54-57. DOI: https://doi.org/10.21495/5896-3-054

9. Prokopenko A. V. Eksperimentalnoe opredelenie koefficientov intensivnosti napryazhenij dlya treshin $\mathrm{s}$ krivolinejnym frontom v slozhnyh detalyah (lopatkah GTD). Problemy prochnosti. 1981. No. 4. 105-111 p. [In Russian].

10. Andrejkiv A. E. Prostranstvennye zadachi teorii treshin. K.: Nauk. dumka, 1982. 348 p. [In Russian].

11. Parton V. Z., Morozov E. M. Mehanika uprugoplasticheskogo razrusheniya. M.: Nauka, 1985. 504 p. [In Russian].

12. Kienzler R., Hermann G. An Elementary Theory of Defective Beams. Acta Mecanica. 1986. Vol. 62. P. 37-46. DOI: https://doi.org/10.1007/BF01175852

13. Pidhurskyi M., Stashkiv M.. Metody vyznachennia KIN dlia defektnykh elementiv vidkrytoho profiliu. Visnyk TDTU. 2006. Vol. 11. No. 2. P. 92-108 p. [In Ukrainian].

14. ANSYS Workbench User's Guide. Release 2020 R1. (C) ANSYS, Inc. 396 p.

15. Meinhard Kuna Finite Elements in Fracture Mechanics. Theory - Numerics - Applications. - Springer Netherlands, 2013. 447 p.

\section{Список використаної літератури}

1. Hobbacher A. F. Recommendations for Fatigue Design of Welded Joints and Components Springer 2nd ed. 2016. XVI. 143 p. DOI: https://doi.org/10.1007/978-3-319-23757-2

2. Винокуров В. А., Куркин С. А., Николаев Г. А. Сварные конструкции. Механика разрушения и критерии работоспособности. М.: Машиностроение, 1996. 576 с.

3. Андрейкив А. Е., Дарчук А. И. Усталостное разрушение и долговечность конструкций. К.: Наук. думка, 1992. 184 с.

4. Bertolini P., Eder M. A., Taglialegne L., Valvo P. S., Stresses in constant tapered beams with thin-walled rectangular and circular cross sections, Thin-Walled Structures. Volume 137. 2019. P. 527-540. ISSN 0263-8231. DOI: https://doi.org/10.1016/j.tws.2019.01.008

5. Franco E. Dotti, Víctor H. Cortínez, Florencia Reguera, Mode I stress intensity factor for cracked thinwalled composite beams. Theoretical and Applied Fracture Mechanics. Volumes 67-68. 2013. P. 38-45. ISSN 0167-8442. DOI: https://doi.org/10.1016/j.tafmec.2013.10.002

6. Longgang Tian, Leiting Dong, Sharada Bhavanam, Nam Phan, Satya N. Atluri, Mixed-mode fracture \& non-planar fatigue analyses of cracked I-beams, using a 3D SGBEM-FEM Alternating Method. Theoretical and Applied Fracture Mechanics. Volume 74. 2014. P. 188-199. ISSN 0167-8442. DOI: https://doi.org/10.1016/j.tafmec.2014.10.002 
7. Pawar, Pravin \& Ballav, Raj \& Kumar, Amaresh. (2016). Finite element method analysis of stress intensity factor in i channel section. Journal of Production Engineering. 19. P. 103-107.

8. Álvarez, Morán \& Seitl, Stanislav \& Miarka, Petr. (2020). Numerical study of universal beam (i section) under bending load with crack. P. 54-57. DOI: https://doi.org/10.21495/5896-3-054

9. Прокопенко А. В. Экспериментальное определение коэффициентов интенсивности напряжений для трещин с криволинейным фронтом в сложных деталях (лопатках ГТД). Проблемы прочности. 1981. № 4. С. 105-111.

10. Андрейкив А. Е. Пространственные задачи теории трещин. К.: Наук. думка, 1982. 348 с.

11. Партон В. 3., Морозов Е. М. Механика упругопластического разрушения. М.: Наука, 1985. 504 с.

12. Kienzler R., Hermann G. An Elementary Theory of Defective Beams. Acta Mecanica. 1986. Vol. 62. P. 37-46. DOI: https://doi.org/10.1007/BF01175852

13. Підгурський М., Сташків М. Методи визначення КІН для дефектних елементів відкритого профілю. Вісник ТДТУ. 2006. Т. 11. № 2. С. 92-108.

14. ANSYS Workbench User's Guide. Release 2020 R1. C) ANSYS, Inc. 396 p.

15. Meinhard Kuna Finite Elements in Fracture Mechanics. Theory - Numerics - Applications. - Springer Netherlands. 2013. 447 p.

\title{
УДК 621.791.052
}

\section{МОДЕЛЮВАННЯ КІН НОРМАЛЬНОГО ВІДРИВУ ДЛЯ ТРІЩИНИ У ТОНКОСТІННІЙ БАЛЦІ ШВЕЛЕРНОГО ПРОФІЛЮ}

\section{Микола Підгурський; Микола Сташків; Іван Підгурський}

\author{
Тернопільський начіональний технічний університет імені Івана Пулюя, \\ Тернопіль, Україна
}

Резюме. Проведено аналіз методів оцінки коефіцієнтів інтенсивності напружень (КІН) $у$ крайових тріщинах, щзо розповсюджуються у профільних швелерних елементах. Зародження та розповсюдження тріщин в таких елементах спричинене змінними в часі зовнішніми силовими навантаженнями. У рамках лінійної механіки руйнування дослідження напружено-деформівного стану рамних конструкиій при наявності в них тріщиноподібних дефектів зводиться до визначення КIH. У результаті проаналізовано можливість застосування до розв 'язку таких задач аналітичних, числових та експериментальних методів. Зазначено, щуо застосування аналітичних методів досить обмежене через складність врахування реального навантаження та геометричних параметрів конструкцій; експериментальні методи важко інтерпретувати для задач з іншою конфігурацією елемента. У зв'язку з ичим для інженерних задач, щзо наведені вище, розглянуто побудову доволі простих, нехай $і$ менш точних залежностей з визначення КІН, в яких менша точність розрахунку компенсується незначною трудомісткістю. Розглянуто два методи визначення КІН для крайової поперечної тріщини, щзо розповсюджується у швелерному профілі: - через номінальні напруження у нетто-перетині та через зміну моменту інериії поперечного перетину профілю. При иььому виділено дві характерні стадї розвитку тріщини у швелерному профілі: наскрізна тріщина зароджується на краю горизонтальної полиці $i$ розвивається вздовж неї; тріщина розповсюджується у вертикальній стінці швелера. Для кожної із стадій отримано поправкові функиії, на основі яких побудовано узагальнюючі поправкові функиіі. Здійснено імітащійне моделювання напружено-деформівного стану швелера з тріщиною методом скінчених елементів. Отримані дані порівнювались з результатами аналітичного розрахунку пропонованими інженерними методами.

Ключові слова: коефіцієнт інтенсивності напружень, крайова тріщина, швелер, метод скінчених елементів.

https://doi.org/10.33108/visnyk_tntu2021.02.078

Отримано 10.05.2021 